\title{
Stem-Diameter Age Relationships of Tam- arix ramosissima in Central Utah
}

\author{
JACK D. BROTHERSON, JOHN G. CARMAN, AND LEE A. SZYSKA
}

\begin{abstract}
The stem-diameter age relationships of salt cedar from 15 study sites in central Utah were investigated. Age prediction equations were generated and found significant $(p<.001)$. Within restricted geographic areas the stem ages of salt cedar could be estimated with fair reliability, but with substantial geographic separation results were less accurate. The impact of salt cedar invasion over prolonged periods of time was also assessed. Results indicated that the longer the community has been occupied by salt cedar the more xeric the habitat becomes.
\end{abstract}

Saltcedar (Tamarix ramosissima) is a vigorous invader of pastures, moist lowlands and stream banks throughout much of the southwestern United States (Tomanek and Ziegler 1960). It is also found in dense thickets through much of central Utah (Christensen 1962). Saltcedar has the highest transpiration rates of any North American phreatophyte (Kiegler 1968) and can depress the water table of ten by as much as 1.2 to $2.1 \mathrm{~m} / \mathrm{yr}$ (Horton 1964). Although studies have been made of the distribution and naturalization of saltcedar (Christensen 1962, and Horton 1964), and of its ecology and habitat requirements (Tomanek and Ziegler 1960, Carman 1979), much less is known of its stem diameter: age relationship and/or population dynamics.

Studies of the growth rings of trees have been used extensively for dating (Douglas 1935, Glock 1937) reconstructing past climates (Fruits 1971, Harper 1979, Schulman 1956, Stockton and Meko 1975) and interpretation of successional dynamics (Burkhardt and Tisdale 1969, Barney 1972). Data on shrubs are relatively rare (Ferguson 1958, 1959; Ferguson and Humphrey 1959) but should be equally valuable.

Brotherson et al. (1980b) included saltcedar in their study of the size and age relations of 8 major tree species of Navajo National Monument, Ariz. The present study considers the stem diameterage relationship of saltcedar from 15 sites in central Utah and compares these relationships with the Arizona saltcedar population.

\section{Methods}

Fifteen study sites were established bordering Utah Lake, Utah County, Utah, at approximately $40^{\circ} 10^{\prime} \mathrm{N}, 19^{\circ} 50^{\prime} \mathrm{W}$. Site elevations ranged from 1,365 to $1,408 \mathrm{~m}$ above sea level with a mean of $1,377 \mathrm{~m}$. The average annual precipitation in the area (as determined for Provo, Utah) is $340 \mathrm{~mm}$ with $60 \%$ of the total falling in the winter and spring months (Carman 1979).

Sixteen stems each were obtained from 5 of the 15 sites. Stems were sectioned diagnally, polished with fine sandpaper, and the annual growth rings counted twice (independently) with the aid of a binocular microscope (Brotherson et al. 1980a). One ring was assumed to equal 1 year's growth. Stem diameters were measured with a diameter tape.

Linear regressions of age on stem diameter generated stem diameter-age predictor equations for each of the 5 populations of saltcedar (Brotherson et al. 1980b). The predictor equations were then checked by estimating the ages of stems of known age. The

\footnotetext{
Authors are associate professor of botany and range Science, Department of Botany and Range Science, Brigham Young University, Provo, Utah 84602; graduate student, Department of Range Science, Texas A\&M University, College Station 77843; and research associate Department of Botany and Range Science, Brigham Young University, Provo, Utah 84602.

Manuscript received September 8, 1980.
}

predictor equations were also used to predict mean ages for the other 10 populations.

Synthetic Stand Moisture Index Values (SSMI), similar to Plot Index Values (PIV) described by Dix and Butler (1960), were constructed for all study sites. This was accomplished by assigning all species found growing in the study sites (with the exception of saltcedar and saltgrass) adaptation numbers corresponding to their general moisture affinities. Xeric species were rated a 1 , the most mesic species were rated a 3, and those species falling in between were rated a 2 . Moisture relationships for each species were determined according to their general habitat requirements. The SSMI values were computed by taking all species in the stand and multiplying their average percent cover by their relative moisture ratings, summing those values and then dividing the total by the sum total of the percent cover of these same species (Bloss and Brotherson 1979). This yields an index (SSMI) between 1 and 3.

\section{Results and Discussion}

All populations of saltcedar generated regression predictor equations significant at the .001 level (Table 1). The age predictor

Table 1. Estimator equations and significance levels for stem age of Tamarix ramosissiona as developed through linear regressions of stem diameter-age data taken from each site and all sites combined. $N=16$ for individual sites, $\mathbf{N}=\mathbf{8 0}$ for combined sites.

\begin{tabular}{lccc}
\hline \hline Estimator site & Equation & $r^{2}$ & Sig. level \\
\hline Airport Dike & $\mathrm{Y}=2.061 \mathrm{x}+4.2874$ & 0.8578 & .001 \\
East of Saratoga & $\mathrm{Y}=3.5422 \mathrm{x}+0.8129$ & 0.8129 & .001 \\
North of Saratoga & $\mathrm{Y}=2.5061 \mathrm{x}+4.3349$ & 0.7727 & .001 \\
$\begin{array}{l}\text { South of Pelican } \\
\quad \text { Point }\end{array}$ & $\mathrm{Y}=3.6133 \mathrm{x}+3.9368$ & 0.7871 & .001 \\
$\begin{array}{l}\text { West of Goshen Bay } \\
\text { All locations }\end{array}$ & $\mathrm{Y}=2.1749 \mathrm{x}+5.4590$ & 0.8324 & .001 \\
$\quad$ combined & $\mathrm{Y}=2.1861 \mathrm{x}+5.6100$ & 0.7358 & .001 \\
\hline
\end{tabular}

equation generated by using all the data points $(\mathrm{N}=80)$ was also significant at .001 level. This indicates a fairly constant relation between size and age for populations of saltcedar in central Utah.

The site-specific predictor equations were then used to estimate ages for each site. There were no significant differences between true age and estimated age (Table 2). Using the combined site

Table 2. Paired $T$ - test findings of true age versus estimated age for each site and all sites combined. $N=16$ for individual sites, $N=80$ for combined sites. $\mathrm{s}=$ standard deviation of true age - estimated age values; $C I=$ confidence interval in years $(P=.05) ; d=$ mean of the absolute values for the true age - estimated age values.

\begin{tabular}{lccccc}
\hline \hline Site & \multicolumn{3}{c}{ Sig. } & & CI \\
level & s & $(1.96 s)$ & $\bar{d}$ \\
\hline Airport Dike & -0.10 & NS & 2.46 & \pm 5 & 1.94 \\
East of Saratoga & 0.20 & NS & 2.47 & \pm 5 & 1.50 \\
North of Saratoga & 0.00 & NS & 2.99 & \pm 6 & 2.38 \\
South of Pelican Point & -0.49 & NS & 3.07 & \pm 6 & 2.63 \\
West of Gosehn Bay & 0.00 & NS & 2.53 & \pm 5 & 2.00 \\
All locations combined & 0.00 & NS & 3.49 & \pm 7 & 2.81 \\
\hline
\end{tabular}


Table 3. Predictive value of the combined site estimator equation when used to eatimate stems from each site. Statistics are from paried $T$ - test results of true and estimated ages. $\bar{d}=$ mean of true age - estimated age values. Positive values of $d$ indicate overestimation; $s=$ standard deviation of true age -estimated age values; C.I. = confidence interval of estimated ages $(P=0.05)$. $u=$ true age. $\vec{d}=$ mean of the absolute values for the true age - estimated age values.

\begin{tabular}{lcccccc}
\hline \hline Combined Estimator on: & $\mathrm{t}$ & Sig. Level & $\mathrm{d}$ & $\mathrm{s}$ & $\mathrm{C} . \mathrm{I}$ \\
\hline Airport Dike & -3.11 & .005 & -2.13 & 2.73 & $-7.5<\mu<3.2$ \\
East of Saratoga & -1.43 & .1 & -0.94 & 2.62 & $-6.1<\mu<4.2$ & 2.63 \\
North of Saratoga & .08 & $\mathrm{NS}$ & 0.06 & 3.07 & 2.31 \\
South of Pelican Point & 3.08 & .005 & 3.13 & 4.06 & $-6.0<\mu<6.1$ & $-4.8<\mu<11.1$ \\
West of Goshen Bay & -0.18 & $\mathrm{NS}$ & 0.13 & 2.80 & $-5.4<\mu<5.6$ \\
\hline
\end{tabular}

predictor equation to estimate ages for all sites gave two significant differences between estimated age and true age (Table 3 ). These 2 sites, Airport Dike and Pelican Point, had the lowest and highest regression slopes (Table 1 ) and it is therefore not surprising that the intermediate-sloped, combined predictor equation should be least accurate with the two extreme populations.

There is a fair amount of variability in growth rates between sites in Utah as indicated by mean diameter/age ratios (Table 4). However, this in-state variability is less than that between states. If we

Table 4. Stem diameter-age ratios for each site and all sites combined. $N=$ 16 ( $N=80$ for all sites combined).

\begin{tabular}{lcc}
\hline \hline Site & $\begin{array}{c}\text { Mean diameter } \\
(\mathrm{cm}) / \text { Age Ratio }\end{array}$ & $\begin{array}{c}\text { Coef. } \\
\text { of. var. }\end{array}$ \\
\hline Airport Dike & .36 & 15.7 \\
East of Saratoga & .24 & 19.9 \\
North of Saratoga & .27 & 24.3 \\
South of Pelican Point & .21 & 22.5 \\
West of Goshen Bay & .31 & 17.8 \\
All sites combined & .28 & 27.1 \\
\hline
\end{tabular}

compare relative growth rates as measured by the number of rings per $\mathrm{cm}$ (Table 5), we find that the average number of rings per $\mathrm{cm}$ of saltcedar in Utah (7.68) is 3.25 times greater that the average number of rings per $\mathrm{cm}$ of saltcedar in Navajo National Monument, Arizona (2.36 rings per $\mathrm{cm}$, as recalculated from Brotherson

Table 5. Comparison of estimator equations of populations of Tamarix ramosissima from Central Utah data from all sites combined) and from populations in Navajo National Monument, Arizona (Brotherson et al. $1980 b)$.

\begin{tabular}{lcc}
\hline & Utah & Arizona \\
\hline Sample & 80 & 72 \\
Predictor equation & Age $=2.9 \mathrm{x}+5.61$ & Age $=1.92 \mathrm{x}+5.56$ \\
$\mathrm{r}$ & .86 & .79 \\
$R^{2}$ & .74 & .62 \\
Significance & .001 & .025 \\
Growth rings/cm & 7.68 & 2.36 \\
Deviation in Age-estimation & & \\
$\quad$ (in years) from true age & $3.1 \pm 2.4^{\mathrm{b}}$ & $4.7 \pm 1.9^{*}$ \\
\hline
\end{tabular}

Arizona on to Utah

'Utah on to Arizona.

et al. 1980b, Table 5). The slope of the regression equation is also steeper for the Utah populations, suggesting a slower annual growth rate, possibly due to a reduced growing season, less annual precipitation or differences in water table level.

Our results also indicate that within a relatively restricted geographic area, stem ages of saltcedar can be estimated with fair reliability from stem diameters and thus become fairly reliable gauges of population dynamics within stands. Substantial geographic separation of stands, on the other hand, may necessitate recalibrating the regression equation, as environmental factors normally affecting growth rates may modify the diameter-age relationship (Brotherson et al. 1980).

The communities invaded by saltcedar in central Utah vary in their general floristic composition. Our data showed a range of 5 to 19 species present with a mean of 12 species. Overall 76 species were encountered. These ranged in habitat preference from marsh to xeric saline meadows. The most important species in the community outside of saltcedar is saltgrass (Distichlis spicata var. stricta). Several other species were also found to be prominant (Table 6) and as shown exhibited variations in their distribution patterns relative to the length of time a site had been occupied by saltcedar.

In an attempt to assess the impact of saltcedar over a prolonged period of time on the moisture conditions of habitats which it invades, a Synthetic Stand Moisture Index (SSMI) was developed for each of the 15 populations (Bloss and Brotherson 1979). The index (SSMI) has been shown to be of value in understanding moisture relationships within and between community types (Bloss and Brotherson 1979, Brotherson and Brotherson 1979) and to closely approximate actual moisture gradients within the community (England 1979).

The SSMI index values were regressed against the average age of the 15 stands (Fig. 1). The relationship is highly significant

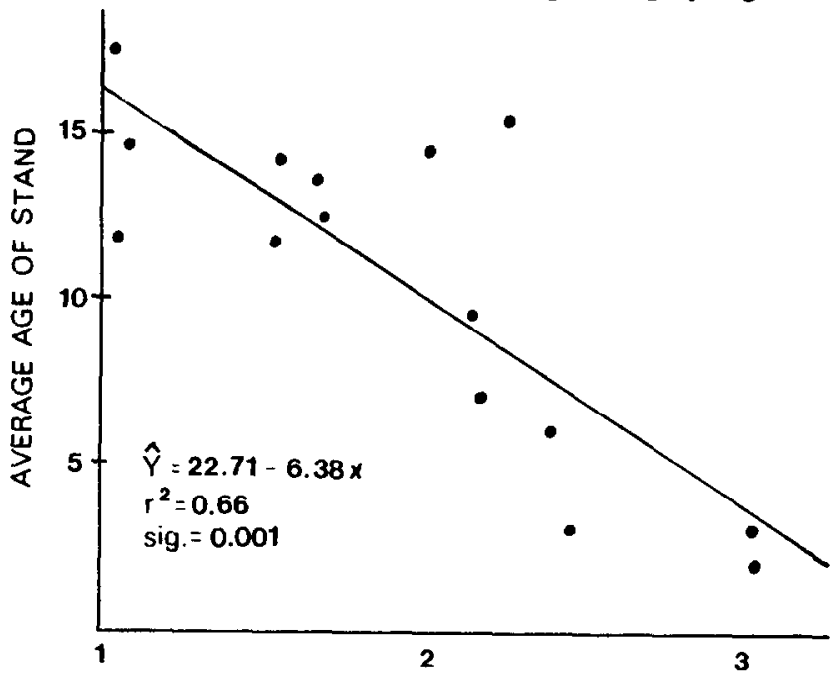

SYNTHETIC STAND MOISTURE INDEX

Fig. 1. Relationship of the synthetic stand moisture index and the average age of the saltcedar community.

$(p<.001)$ and indicates that the longer the community has been invaded by saltcedar the more xeric in nature are the plant species which occupy the understory.

In a second attempt to get at this same relationship the 15 stands were divided into 5 groups of 3 and the cover values for only xeric annuals were summed and averaged. These values were then regressed against the mean ages of the stands in each group (Fig. 2). Again the relationship is highly significant $(p<.001)$ indicating that the longer the site is occupied by saltcedar the more xeric the 
Table 6. Prevalent species list along with average cover values in overall community as well as average cover values in the five age groups. The prevalent species list represents the average number of species per stand or study plot within the community.

\begin{tabular}{|c|c|c|c|c|c|c|}
\hline \multirow[b]{2}{*}{ Species } & \multirow{2}{*}{$\begin{array}{c}\text { Average } \\
\text { cover }\end{array}$} & \multicolumn{5}{|c|}{ Average cover by age groups } \\
\hline & & $2.0-3.1$ & $6.0-9.6$ & $11.8-12.2$ & $13.6-14.5$ & $14.7-17.4$ \\
\hline Tamarix ramosissima & 12.7 & 38.1 & 73.8 & 40.3 & 73.1 & 70.6 \\
\hline Distichlis spicata var. stricta & 10.8 & 29.5 & 62.5 & 34.5 & 51.9 & 45.2 \\
\hline Kochia scoparia & 3.0 & & 5.9 & 12.3 & 6.4 & 35.9 \\
\hline Cardaria draba & 1.7 & & 24.9 & & & \\
\hline Iva axillaris & 1.5 & & & 5.7 & 7.1 & 9.6 \\
\hline Polypogon monspeliensis & 1.2 & 11.6 & 8.7 & .6 & 2.9 & 10.4 \\
\hline Cynodon dactylon & 1.1 & 31.3 & & & & \\
\hline Atriplex patula & 1.1 & 7.0 & 10.9 & .1 & 10.1 & .3 \\
\hline Bromus tectorum & 1.0 & & & .8 & & 3.7 \\
\hline Hordeum jubatum & .7 & & & & & 2.3 \\
\hline Poa pratensis & .7 & & & 18.5 & & \\
\hline Juncus balticus & .6 & & & & 9.4 & \\
\hline
\end{tabular}

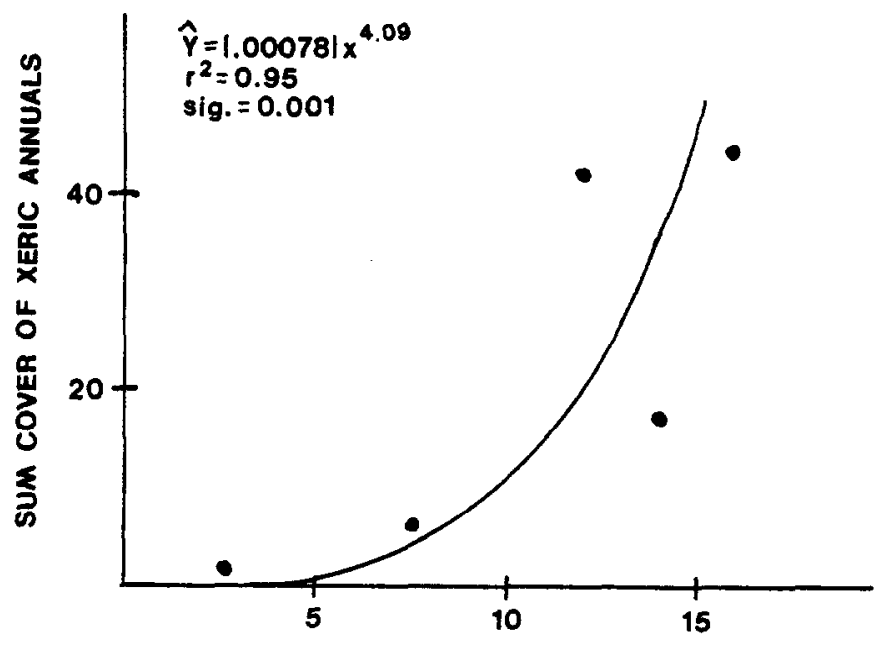

AVERAGE AGE OF STAND

Fig. 2. Relationship between average age of the salt cedar study sites and the importance of xeric annuals in the understory.

habitat becomes. These data support other studies on saltcedar invasion which indicate its capacity to lower the water table in the soil and thus cause an overall drying out of habitat (Kiegler 1968, Horton 1964).

\section{Literature Cited}

Barney, M.A. 1972. Vegetation changes following fire in the pinyon-juniper type of west central Utah. M.S. Thesis, Brigham Young University, Provo, Utah.

Burkhardt, J.W., and E.W. Tisdale. 1969. Nature and successional status of western juniper vegetation in Idaho. J. Range Manage. 22:264-270.

Bloss, D.A., and J.D. Brotherson. 1979. Vegetation response to a moisture gradient on an ephemeral stream in central Arizona. Great Basin Naturalist 39:161-176.

Brotherson, J.D. and K.J. Brotherson. 1979. Ecological and community relationships of Eriogonum corymbosum (Polygonaceae) in the Uinta Basin, Utah. Great Basin Naturalist 39:177-191.

Brotherson, J.D., J.N. Davis, L. Greenwood. 1980. Diameter-age relationships of two species of mountain mahogany. J. Range Manage. 33:367-370.
Brotherson, J.D., S.R. Rushforth, W.E. Evenson, J.R. Johansen, C. Morden. 1980. Population dynamics and age relationships of eight tree species in Navajo National Monument, Arizona. J. Range Manage. 36:250-256.

Carmen, J.G. 1979. Comparative ecology: A study of sites invaded by Tamarix ramosissima and Elaeagnus angustifolia in central Utah. Unpubl. M.S. Thesis, Brigham Young University.

Christensen, E.M.1962. The rate of naturalization Tamarix in Utah. Amer. Midl. Natur. 68:51-57.

Dix, R.L., and J.E. Butler. 1960. A phytosociological study of a small prairie in Wisconsin. Ecology 41:316-327.

Douglas, A.E. 1935. Climatic cycles and tree growth I: A study of the annual rings of trees in relation to climate and solar activity. Carnegie Institute Washington, Publ. No. 289, Vol. 1, Washington.

England, J.L. 1979. Measured and inferred moisture gradient relationships: a study of a montane steppe in central Utah. Unpubl. M.S. thesis. Department of Botany and Range Science, Brigham Young University, Provo, Utah.

Ferguson, C.W. 1958. Growth rings in Big Sagebrush as a possible aid in dating archaeological sites. p. 210-211. In: A.E. Dittert Jr., ed. Recent Developments in Navajo Project Salvage Archaeology. El Palacio 65:201-211.

Ferguson, C.W. 1959. Growth rings in woody shrubs as potential aids in archaeological interpretation. The Kiva 25:24-30.

Ferguson, C.W., R.R. Humphrey. 1959. Growth rings on big sagebrush reveal rainfall records. Prog. Agr. in Ariz. 11:3.

Fritts, H.C. 1971. Dendroclimatology and dendroecology. Quaternary Res. 1:419-449.

Glock, W.S. 1937. Principles and methods of tree-ring analysis. Carnegie Institute Washington, Pub. No. 486, Washington.

Harper, K.T. 1979. Dendrochronology - dating with tree rings. In: W. M. Hess and R.T. Matheny, eds. Science and Religion: Toward a More Useful Dialogue, Vol. 1. Paladin House Pub., Geneva, IIl.

Horton, J.S. 1964. Notes on the introduction of deciduous Tamarix. U.S. Forest Service Research Note RM-16.

Kiegler, J.G. 1968. The phenomenal spread of saltcedar in the West. Engineering Station, Technical Division, New Mexico State Engineering Office, unpub. paper.

Schulman, E. 1956. Dendroclimatic changes in semi-arid America. Univ. of Arizona Press Tucson.

Stockton, C.W., D.M. Meko. 1975. A long-term history of drought occurrence in western United States as inferred from tree rings. Weatherwise 28:245-249.

Tomanek, G.W., and Ziegler. 1960. Ecological studies of salt cedar. Unpublished Report. Division of Biological Sciences, Fort Hays Kansas State College, Hays, Kansas. 